\title{
Target Therapy in Platinum-Refractory/Resistant Ovarian Cancer: From Preclinical Findings to Current Clinical Practice
}

\author{
Nicoletta Staropoli, Cirino Botta, Domenico Ciliberto, Lucia Fiorillo, Antonina Maria De Angelis, \\ Caterina Viscomi, Simona Gualtieri, Angela Salvino, Pierfrancesco Tassone, Pierosandro Tagliaferri
}

Medical Oncology Unit, Department of Experimental and Clinical Medicine, Magna Græcia University and Tommaso Campanella Cancer Center, Campus Salvatore Venuta, Catanzaro, Italy.

Email: tagliaferri@unicz.it

Received March 28 ${ }^{\text {th }}, 2013$; revised April 30 ${ }^{\text {th }}, 2013$; accepted May $7^{\text {th }}, 2013$

Copyright (C) 2013 Nicoletta Staropoli et al. This is an open access article distributed under the Creative Commons Attribution License, which permits unrestricted use, distribution, and reproduction in any medium, provided the original work is properly cited.

\begin{abstract}
Epithelial ovarian cancer (EOC) is the sixth most common malignancy in women. Ovarian tumors consist of several clinical and pathological entities that share an anatomic site. The gold standard treatment, both in front-line and in adjuvant setting, is represented by carboplatin/paclitaxel combination. Conversely, the second-line treatment is not well defined. The response to platinum is the major prognostic factor for survival. In this review we discuss the current views on platinum-refractory/resistant patient treatment only, which includes patients progressing or relapsing within 6 months from the last platinum-based course. Concerning this subgroup, the activity of several conventional drugs was confirmed in different trials without a significant impact in terms of overall survival. In the last years particular emphasis was given to targeted anti-angiogenetic therapy which produced a survival improvement with an acceptable toxicity profile. New "ad hoc" approaches, with a major attention to outcome-predictive factors, are eagerly awaited.
\end{abstract}

Keywords: Ovarian Cancer; Systemic Chemotherapy; Platinum Sensitivity Status

\section{Introduction}

Epithelial ovarian cancer (EOC) is the sixth most common malignancy in women [1]. The overall 5 -years survival rate, despite of stage, is about $30 \%$ [2]. Serous papillary EOC is the most frequent type and the leading cause of death among gynaecological cancers. EOCs consist of several pathological entities that share anatomic site and frontline treatment [3]. Indeed, mutations that arise in EOC, such as KRAS, PIK3CA, TP53, BRCA1 and BRCA2, are unequally distributed between different subtypes [4]. Kurman et al. described that only serous papillary EOC seems to originate by ovary and/or fallopian tube, and in the contest of this histotype two different groups are recognized: Type I tumors arise by precursor lesion, are usually low grade with specific mutations in K-RAS, B-RAF, PTEN and b-catenin, present a normal karyotype and wild-type TP53. These mutations are frequently reported very early and typically these tumors are characterized by a worse response to platinum-based chemotherapy. The course of these lesions is indolent and has been postulated to be the result of "multi-hit oncogenesis". Conversely Type II is characterized by de novo lesions, high grade, genetic instability, TP53 mutations, RAS pathway wild-type, and BRCA mutations, both hereditary and sporadic (such as promoter methylation and failure in the DNA homologous recombination); last subgroup showed a strongly correlation with response to platinum, probably due to early loss of BRCA and TP53 function (Table 1) [5-13].

In 1991, a meta-analysis on 8000 patients showed that platinum-based combination regimens were more effective compared to platinum monotherapy [14]. Currently, the gold standard treatment in frontline and in adjuvant setting is carboplatin/paclitaxel [15-17]. Conversely, the treatment for recurrent or progressive EOC is not well defined. The response to platinum-containing first line chemotherapy is the major prognostic factor. Platinum-refractory status is generally considered for patients who relapse within 6 months from the last platinum-based course [7]. Concerning this subgroup, in the last years, a modest activity of several drugs such as pegylated liposomial doxorubicin (PLD), topotecan, eto- 
Table 1. Characteristics of Type I and Type II tumor.

\begin{tabular}{|c|c|c|}
\hline & Type I & Type II \\
\hline Clinical features & indolent & aggressive \\
\hline \multirow[t]{4}{*}{ Histological features } & low-grade serous & high-grade serous \\
\hline & low-grade endometrioid & $\begin{array}{l}\text { high-grade } \\
\text { endometrioid }\end{array}$ \\
\hline & clear cell & undifferentiated \\
\hline & mucinous & Carcinosarcoma \\
\hline \multirow[t]{6}{*}{ Molecular features } & K-RAS & TP53CCNE1 \\
\hline & B-RAF & \\
\hline & ERBB2 & \\
\hline & PTEN & \\
\hline & CTNNB1 & \\
\hline & PIK3CA & \\
\hline
\end{tabular}

poside, taxanes, gemcitabine, oxaliplatin was confirmed in several trials without a significant impact in terms of overall survival (OS). Therefore, there is not a standard approach for second-line treatment $[18,19]$.

\section{Cytotoxic Chemotherapy}

The platinum-refractory/resistant diseases represent an heterogeneous spectrum of tumors characterized by low response rate (RR) to previous carboplatin-based-schedule $(10 \%-25 \%)[18,20,21]$. Conventional decision in this setting is exclusion of platinum in subsequent linetreatment [19]. Indeed, common recommendation can be made for the use of monotherapy with PLD, topotecan, etoposide, gemcitabine or paclitaxel, all producing a low RR without any demonstrated improvement on survival endpoints [18,21].

In 2004 results by Gordon et al. described a marginal progression free survival (PFS) benefit for PLD compared to topotecan (especially in platinum-sensitive subgroup) that, in view of the good tolerability of the drug, was translated in platinum-refractory setting. PLD became a "first" choice for second-line treatment in all subgroups [22]. Subsequently, several trials did not demonstrate statistically significant results in terms of survival gain for PLD compared to gemcitabine, that remains therefore a valid option in this setting with RR of $20 \%$ [23-31]. By the way gemcitabine was the most common drug used in clinical trials $[32,33]$.

In recent studies pemetrexed, a multitarget antifolate agent, produced RR similar to historical agents without any evident impact in term of survival [34-36]. Rose et al. investigated prolonged oral etoposide in both platinumsensitive and platinum-resistant patients with an overall RR of $34 \%$ and $27 \%$ respectively [37].
Paclitaxel, as single agent, represents to date, a good clinical option in term of RR and survival, in particular if we consider weekly schedule $[38,39]$. Furthermore, the albumin-bound formulation of paclitaxel, nab-paclitaxel too, has been investigated in this setting showing similar RR $(23 \%)$ and a median PFS of 4.7 months with a good tolerability [40].

A larger study with docetaxel in monotherapy was conducted by Rose et al. in platinum and paclitaxel-refractory settings with a RR of $22 \%$ [41]. The potential role of docetaxel-based combination regimens has not been rigorously evaluated. A prospective phase II study was conducted to evaluate the efficacy and toxicity of a combination of docetaxel/irinotecan as salvage treatment in platinum-refractory EOC patients [42]. This non-comparative trial, demonstrated a marginal benefit in RR similar to single agent schedule, confirming that single agent chemotherapy should be considered the standard treatment for these patients. Indeed, six trials failed to demonstrate an advantage for combination treatment compared to single agent with an increased toxicity [4351].

However, different small trials evaluating gemcitabine and oxaliplatin combination in this setting demonstrated a longer PFS and a better RR. Considering the worse prognosis of these patients, comparative studies of this doublet versus single agent are required [52,53].

In third-line treatment a randomized phase III trial comparing PLD to patupilone, a novel microtubule inhibitor, demonstrated a PFS advantage for PLD arm [54]. Similarly canfosfamide, compared to topotecan and PLD in second- and third-line treatment, have been found significantly less active than these drugs [55-58].

In the light of the dismissal activity of conventional chemotherapy, in the last years particular emphasis was given to targeted therapy which produced survival improvement with an acceptable toxicity [59-63].

\section{Targeted Therapy in EOC}

\subsection{The Involvement of HER-Pathway in Platinum-Resistance}

The epidermal growth factor receptor (EGFR)-family play an important role in different malignancies and a EGFR overexpression seems to be correlated with decreased survival [64]. About 30\% - 98\% of EOC present overexpression in one of these pathways. Human epidermal receptor (HER) family consist of 4 paralogs (HER1/EGFR, HER2/neu, HER3 and HER4) and is characterized by an extracellular ligand binding domain, a transmembrane lipophilic glycoprotein and an intracellular tyrosine kinase (TK) domain. Signaling cascade begins with bindings of growth factors, such as epidermal 
growth factor (EGF), transforming growth factor alfa $(\mathrm{TGF}-\alpha)$ to the receptor and subsequent dimerization or oligomerization and has been implicated in cancer development and resistance to cisplatin [65]. EGFR determines both omo-dimerization and ethero-dimerization with HER2/neu. The receptor triggers the autophosphorylation on tyrosine residues with signal transduction cascade activation. Dysregulation in EGFR promotes cell proliferation, migration and invasion with uncontrolled cellular growth and enhanced neo-angiogenesis [66]. Dimerization activates different signaling pathways, in particular EGFR dimerization activates the RAS-RAF-mitogen-activated protein kinase pathway (RAS/RAF/ MAPK pathway) which induces oncogenesis and tumor progression mainly through constitutive activation of STAT-3 and STAT-5 and the phosphatidylinositol 3-kinase pathway (PI3K). Activation of PI3K results in the activation of the PDK1, AKT/PKB pathway [67].

Cetuximab is a chimeric monoclonal antibody able to inhibit the binding of EGF and the autophosphorylation of the receptor with its internalization from the cell surface that prevents further interaction with ligand [68]. A small phase II trial designed on platinum-refractory/resistant EGFR positive setting on cetuximab as single agent demonstrated marginal benefit in term of PFS [69]. Matuzumab, a humanized anti-EGFR monoclonal antibody, in patients heavily pretreated, did not show activity in this setting [70].

Erlotinib, a reversible EGFR-specific tyrosine kinase inhibitor (TKI), was evaluated as single-agent in two phase II trials that enrolled patients with platinum-resistant status obtaining a marginal activity limited for patients with EGFR-positive EOC. These trials reported a median OS of 8 months and disease control rate (DCR) in $50 \%$ of patients with acceptable tolerability [71].

Gefitinib was evaluated in phase II trial in patients with platinum-resistant setting and EGFR positive, with median PFS 2.2 months and RR 9\% [72]. Another trial in this setting, evaluated the combination gefitinib/tamoxifen with a median time-to-progression of 58 days and median survival of 253 days [73]. Furthermore gefitinib was evaluated in combination with carboplatin and paclitaxel in patients stratified for platinum-sensitivity and EGFR positive and suggested advantages for platinumsensitive setting only [74].

Trastuzumab, a monoclonal antibody targeting the HER2/neu, was investigated in a phase II trial on the basis of HER2/neu expression. This trial showed that activity of trastuzumab in this setting is limited by the low frequency of HER2 overexpression and low rate of objective response among patients with HER2 overexpression [75]. CI-1033 (canertinib), another panERB inhibitor also failed to demonstrate activity in platinum- refractory/resistant patients [76]. Lapatinib a 4-anilinoquinazoline, is an inhibitor of the intracellular TK domains of both EGFR and HER2. It was investigated in phase II trials both as single agent and in combination with topotecan but was not effective. Interestingly, in this trial, a subset analysis about prognostic factors suggested that Ki-67 expression may be associated with better prior platinum free interval (PFI) and PFS [77,78].

Pertuzumab is a recombinant, humanized monoclonal antibody directed against human HER2 that inhibits ligand-activated heterodimerization with other HERs, most notably HER3 [79]. A phase II trial evaluated pertuzumab in combination with gemcitabine in platinumresistant EOC treatment demonstrated a significant advantage in term of RR and PFS for experimental arm compared to gemcitabine/placebo. Furthermore, it was suggested that patients with low HER3 mRNA expression, had an increase treatment benefit with pertuzumab [80].

\subsection{Potential Role of $\mathbf{m T O R}$ Inhibitors and Platinum-Refractory/Resistant Ovarian Cancer}

mTOR is a serine and threonine protein kinase. The mTOR pathway is involved in cell proliferation, motility and survival, protein synthesis and transcription. Preclinical findings indicated that this pathway has a crucial role in survival and drug-resistance of cancer cells. A small phase II trial evaluated efficacy and toxicity profile of mTOR inhibitor, temsirolimus, in platinum-resistant EOC disease and showed a modest activity. Cyclin D1 and circulating tumors cells (CTCs) measures where suggested as markers of outcome [81].

\subsection{PARP Inhibitors}

About $50 \%$ of EOC display defects in the homologous recombination (HR) pathway. This condition, like hereditary mutation in BRCA1-2, correlated to a good response to platinum-chemotherapy. However, Kaye et al., evaluated use of olaparib, a PARP inhibitor, compared to PLD in patients who relapsed within 12 months did not reach pre-specified endpoints, failing to demonstrate any advantage for olaparib [82].

\subsection{The Strict Interplay between Inflammation, Immune-System and Angiogenesis}

The role of inflammation, immune system and angiogenesis in the onset and development of EOC has been extensively investigated during the past years $[83,84]$. The synthesis of cytokines such as TNF- $\alpha$, IL- $1 \beta$, IL- 6 , PGE-2 and vascular endothelial growth factor (VEGF) 
by cells from the microenvironment (especially activated immune cells and stromal cells), as well as the increased expression of STAT-3, NF-kB, iNOS and COX-2 in tumor and tumor-surrounding cells, has been linked to poor prognosis, disease stage progression, residual disease status and the presence of ascites $[83,85,86]$. Among these molecules, IL-6 seems to play a key role in determining platinum-resistance. Wang et al. recently reported that IL- 6 production by different EOC cell lines is directly associated to treatment resistance. Furthermore, IL-6 induced cisplatin and paclitaxel-resistance when administered to IL-6-non-producing cell lines [87]. The ERK signaling pathway seems the principal mediator of this effect. Furthermore, IL-6 is able to induce HIF-1 via STAT-3, and HIF-1, in turn, promotes VEGF expression [88-90]. VEGF is able to enhance the malignant potential of EOC cells through the induction of ascites, by increasing peritoneal permeability and immune suppression, by impairing dendritic cells maturation and Th1 response and increasing tumor-infiltration by $\mathrm{T}$ regulatory cells [91-93]. Moreover, Bamias et al. described an association between VEGF levels in ascites and platinum-resistance and an inverse correlation of VEGF with $\mathrm{CD}^{+} \mathrm{CD}^{+} 6^{+}$Natural Killer (NK) cells [94]. On these basis it emerges the central role of inflammation in platinum-refractory EOC: the inflammatory microenvironment induces the production and release of IL- 6 and VEGF which in turn lead to neo-angiogenesis, ascites formation and immune suppression on both adaptive (DCs and Th1) and NK immunity.

Tumor infiltration by different inflammatory cells has been correlated with prognosis and tumor progression in different tumors including EOC [95-98]. Among these cells, tumor associated macrophages (TAMs) have recently demonstrated to exert a significant immune suppressive effect together with a pro-angiogenic activity (M2 polarization) [99]. M2-TAMs are characterized by the expression of the angiopoietin receptor TIE- 2 and are thought to be implied in VEGF-independent neo-angiogenesis [100]. These aspects are extremely relevant in a translational view, offering a solid rationale for the use of anti-angiogenic agents in platinum-resistant EOC.

\subsection{Anti-Angiogenetic Agents in Platinum-Resistant Ovarian Cancer}

Bevacizumab, antibody targeting VEGF-A, demonstrated clinical activity in recurrent EOC [101,102]. A small trial reported for heavily pre-treated patients with platinumresistant treated with bevacizumab as single agent a median PFS of 4.4 months and a median OS of 10.7 months [59].

Preclinical studies showed an improvement of anti- tumor activity when anti-VEGF or anti-VEGFR targeting agents were associated to cytotoxic agent, probably due to vascular normalization $[103,104]$. A phase II trial described that the association of bevacizumab and metronomic oral cyclophosphamide produced a median OS of 16.9 months [105]. Another phase II trial, that investigated a combination of bevacizumab and nab-paclitaxel reported a median PFS of 8.3 months and a median OS of 16.5 months [106].

Recently results of AURELIA trial, designed for this setting, reported that association of bevacizumab to conventional agents (PLD, topotecan or paclitaxel) was able to prolong PFS. In particular the arm containing weeklypaclitaxel/bevacizumab determined a 10.4 months PFS [60].

Aflibercept, is a recombinant fusion protein between the constant region $(\mathrm{Fc})$ of an $\mathrm{IgG} 1$, the second domain of VEGFR-1 and the third domain of VEGFR-2 that binds and neutralizes VEGF A, B and placental growth factor (PIGF) [107]. This agent seems particularly active in recurrent EOC patients with malignant ascites [108, 109].

Imatinib and dasatinib, selective inhibitors of PDGFR and C-KIT, were evaluated in small phases II trials in recurrent EOC without any improvement both in RR and in survival endpoints $[110,111]$.

Sorafenib, a multitarget inhibitor of B-RAF, VEGFR-2 and -3, PDGFR-b, FLT-3, and C-KIT, was evaluated in phase II trials in second and third line treatment, demonstrating a modest activity and substantial toxicity [112, 113]. Sunitinib, another multi-target TKI for VEGFR, PDGFR-A, PDGFR-B, C-KIT, FLT-3 and cediranib, a potent inhibitor of VEGFR, PDGFR-B and C-KIT, were evaluated as single agents and in combination schedules, in recurrent EOC patients with modest activity in terms of RR and and mostly restricted to the platinum-sensitive setting [114-117].

Pazopanib a TKI targeting VEGFR, PDGFR, and C-KIT, and BIBF-1120, a VEGFR, PDGFR, and FGFR multi-targeted TKI were recently evaluated in combination-schedules and as single agents in EOC patients. Data available, to date, showed activity of these agents and major trials are still ongoing [61,62,118].

Recently a phase II trial evaluated AMG-386, an investigational peptide- $\mathrm{Fc}$ fusion protein that neutralizes the interaction between the TIE-2 receptor and angiopoietin- $1 / 2$, in combination with weekly paclitaxel demonstrated the potential efficacy of this agent, with a good toxicity profile, warranting further studies [119].

Many authors proposed proangiogenic protein concentration in plasma or urine (e.g., VEGF, PDGF, PIGF) as markers that would predict response to anti-angiogenic 
therapy. Several ongoing trials could confirm this hypothesis.

\subsection{MicroRNAs, New Potential Targets in Platinum-Refractory/Resistant EOC}

MicroRNAs (miRNAs), are short non-coding RNA molecules of about $19-25$ nucleotides able to regulate gene expression at post-trascriptional level by binding specific target mRNAs $[120,121]$. Several recently published studies focus their attention on the role played by these molecules in EOC initiation and progression. miR-21 is one of the most widely investigated miRNA due to its pro-oncogenic activity demonstrated in different malignancies [122]. This miRNA is upregulated by the IL-6 downstream (described in previous section) and was found to be overexpressed in platinum-resistant EOC cell lines. In the same study, Lou et al. reported that the down-regulation of miR-21induced apoptosis and inhibited invasion and migration capabilities of EOC cell line, making this miRNA a possible candidate for future clinical translation [123].

About $63 \%$ of platinum-resistant EOC presented a dysfunctional TP53 pathway [124]. This event leads to the reduction of intracellular of the oncosuppressor miR$34 \mathrm{a}$, thus improving cell capability to survive and metas- tatize [125]. In different studies in vitro and in vivo, in different tumors, miR-34 replacement/overexpression induced apoptosis and reduced cellular migration, proliferation and tumor growth $[125,126]$.

The miR-200 family represents another widely studied group of miRNA in EOC. They appeared to be implied in epithelial to mesenchimal transition and in resistance to both paclitaxel and platinum [120]. However, contrasting data on activity and expression of these miRNAs in EOC are available in literature and its role is far to be completely understood.

Non-coding RNAs represent one of the most exciting recent discovery in cancer biology and other different miRNAs, such as miR-29b or miR-221/222 are currently under investigation in different malignancies for their potential clinical application as anticancer agents [127132].

\section{Conclusions}

Figure 1 and Table 2, describe all major pathways mentioned in our review. In the light of clinical trials results it is evident, to date, that only antiangiogenic agents (in particular bevacizumab) when associated to cytotoxic drugs are able to improve EOC patient outcome. Concerning other described pathway, probably pertuzumab

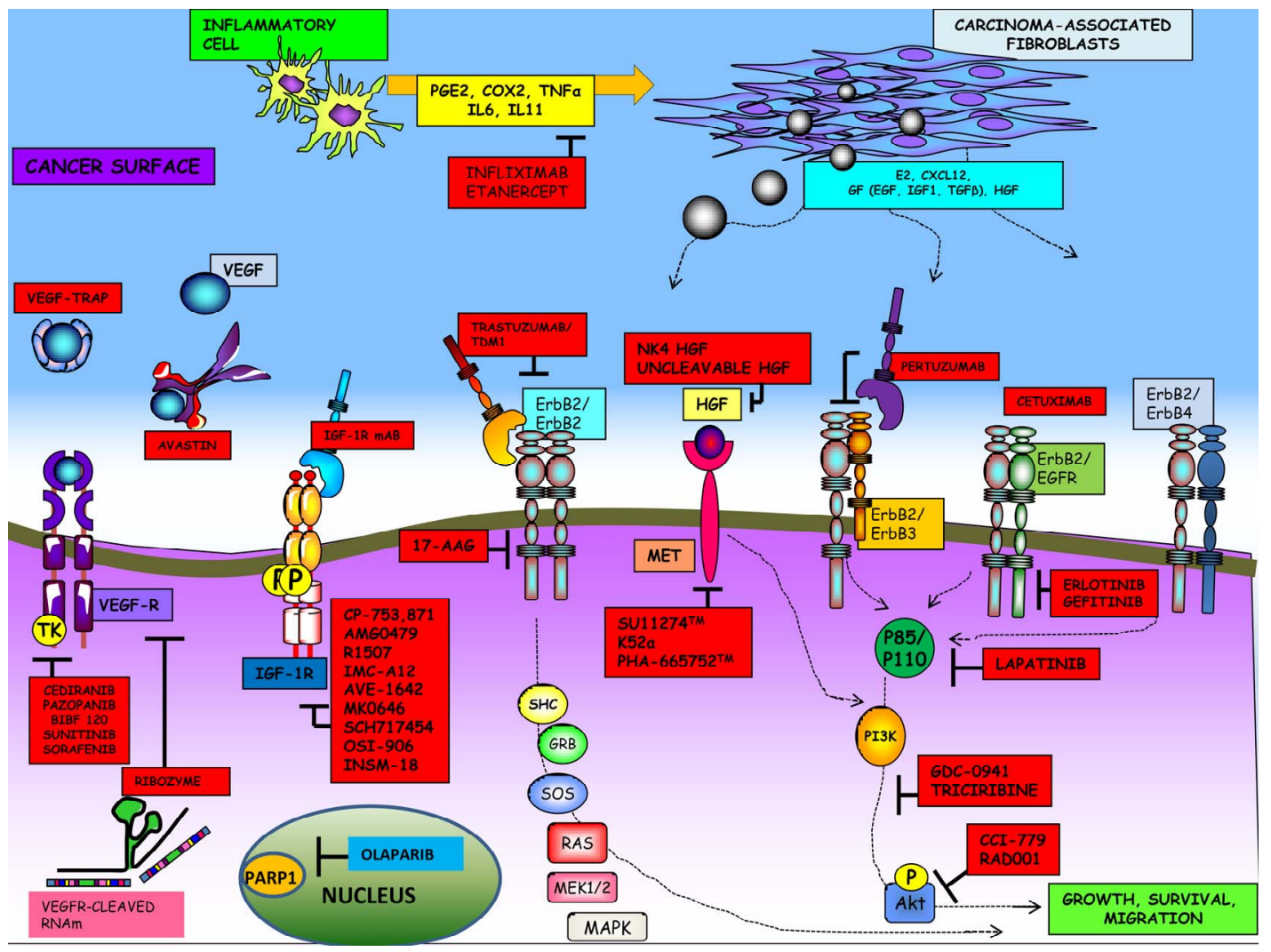

Figure 1. Major pathways involved in EOC pathogenesis and new potential targets. 
Table 2. Phase II III studies targeting EOC.

Study No.pts Patients Treatment $\quad$ RD $\quad$ SD Median PFS Median OS Most common grade $\geq 3$ AE

\begin{tabular}{|c|c|c|c|c|c|c|c|}
\hline $\begin{array}{l}\text { Cannistra } \\
\text { et al. }[59] \\
\text { No. } 44\end{array}$ & $\begin{array}{c}\text { Platinum-resistant } \\
\text { EOC/PSC after } 2 \text { - } 3 \mathrm{CT} \\
\text { regimens }\end{array}$ & $\begin{array}{l}\text { Bevacizumab } 15 \mathrm{mg} / \mathrm{kg} \mathrm{IV} \\
\text { q3 weeks; median no. of } \\
\text { cycles, } 5\end{array}$ & $16 \%$ & $61 \%$ & 4.4 months & 10.7 months & $\begin{array}{c}\text { GI perforation }(11 \%), \\
\text { small intestinal obstruction }(9 \%), \\
\text { Hy }(9 \%), \mathrm{Fg}(5 \%), \\
\text { abdominal pain }(5 \%), \\
\text { or digestion }(5 \%) \\
\text { and dyspnea }(5 \%)\end{array}$ \\
\hline $\begin{array}{c}\text { Pujade-Lauriaine } \\
\text { et al. }[60] \\
\text { No. } 361\end{array}$ & $\begin{array}{c}\text { Platinum/resistent EOC } \\
\text { after } 1 \text { - } 2 \text { CT regimens No } \\
\text { history of bowel } \\
\text { obstruction/abdominal } \\
\text { fistula, or } \\
\text { clinical/radiological } \\
\text { evidence of rectosigmoid } \\
\text { encolvement }\end{array}$ & $\begin{array}{l}\text { Bevacizumab } 15 \mathrm{mg} / \mathrm{kg} \mathrm{IV} \\
\text { q3 weeks and } / \mathrm{or} \mathrm{CT}^{\mathrm{a}}\end{array}$ & NR & NR & 6.7 months & NR & $\begin{array}{c}\text { Netropenia } \\
(23 \% \text { with } \mathrm{P} ; 19 \% \text { with } \mathrm{T}), \\
\text { PSN }(35 \% \text { grade } \geq 2 \text { with P), } \\
\text { HFS }(28 \% \text { grade } \geq 2 \text { with PLD }), \\
\text { Hy }(12 \% \text { with PDL })\end{array}$ \\
\hline $\begin{array}{l}\text { Burger } \\
\text { et al. }[102] \\
\text { No. } 62\end{array}$ & $\begin{array}{l}\text { Persistent/recurrent EOC or } \\
\text { PPC after } 1 \text { - } 2 \text { CT regimens }\end{array}$ & $\begin{array}{c}\text { Bevacizumab } 15 \mathrm{mg} / \mathrm{kg} \mathrm{IV} \\
\text { q3 weeks; median no. of } \\
\text { cycles, } 7\end{array}$ & $21 \%$ & $52 \%$ & 4.7 months & 16.9 months & Hy $(10 \%)$ and GI events ( $7 \%)$ \\
\hline $\begin{array}{l}\text { Garcia } \\
\text { et al. }[104] \\
\text { No. } 70\end{array}$ & $\begin{array}{l}\text { Recurrent EOC or PPC } \\
\text { after } 1 \text { - } 3 \text { CT regimens }\end{array}$ & $\begin{array}{l}\text { Bevacizumab } 10 \mathrm{mg} / \mathrm{kg} \text { IV } \\
\text { q2 weeks and } \\
\text { cyclophosphamide } 50 \mathrm{mg} \text { daily } \\
\text { orally; median no. of cycles, } 5\end{array}$ & $24 \%$ & $63 \%$ & 6 months & 16.9 months & $\begin{array}{l}\text { Lymphopenia (14 episodes), } \\
\text { pain ( } 13 \text { episodes), } \\
\text { Hy ( } 11 \text { episodes }), F g \text { ( } 6 \text { episodes }), \\
\text { and GI obstruction ( } 5 \text { episodes). }\end{array}$ \\
\hline $\begin{array}{l}\text { Tillmanns } \\
\text { et al. }[106] \\
\text { No. } 48\end{array}$ & $\begin{array}{l}\text { Recurrent/platinum-resistant } \\
\text { EOC/PPC after } \geq 1 \text { prior } \\
\text { regimen }\end{array}$ & $\begin{array}{l}\text { Bevacizumab } 10 \mathrm{mg} / \mathrm{kg} \mathrm{IV} \\
\text { q2 weeks and nabpaclitaxel } \\
100 \mathrm{mg} / \mathrm{m}^{2} ; \text { median no. of } \\
\text { cycles, until progression }\end{array}$ & $46 \%$ & 30.8 & 8.3 months & 16.5 months & $\begin{array}{c}\text { Bowel obstruction }(4 \%), \\
\text { nausea }(4 \%) \text {, and nose bleed }(4 \%)\end{array}$ \\
\hline $\begin{array}{l}\text { Wagner } \\
\text { et al. }[73] \\
\text { No. } 56\end{array}$ & $\begin{array}{l}\text { Recurrent/platinum-resistant } \\
\text { EOC/FTC/PPC; had } \\
\text { previously received } \\
\text { first-line platinum/taxane } \\
\text { treatment only }\end{array}$ & $\begin{array}{c}\text { Tamoxifen } 40 \mathrm{mg} / \text { day PO } \\
\text { and gefitinib } 500 \mathrm{mg} / \text { day PO } \\
\text { until progression or } \\
\text { unacceptable toxicity }\end{array}$ & NR & NR & 58 days & 253 days & $\begin{array}{c}\text { Diarrhea (NR\%) and } \\
\text { acne-like skin rash (NR\%) }\end{array}$ \\
\hline $\begin{array}{l}\text { Pautier } \\
\text { et al. }[74] \\
\text { No. } 28\end{array}$ & $\begin{array}{l}\text { Recurrent/platinum-resistant } \\
\text { EOC/FTC/PPC; had } \\
\text { previously received } \\
\text { first-line platinum/taxane } \\
\text { treatment only }\end{array}$ & $\begin{array}{l}\text { Gefitinib } 500 \mathrm{mg} / \text { day PO, P } \\
\left(175 \mathrm{mg} / \mathrm{m}^{2} 3 \mathrm{~h}\right. \\
\text { infusion) and C (AUC 5) every } \\
3 \text { weeks, followed } \\
\text { by gefitinib alone, } \\
\text { median no. of received } \\
\text { cycles } 6 \text { - } 8 \text {. }\end{array}$ & NR & NR & 6.1 months & 16.9 months & $\begin{array}{c}\text { Neutropenia }(59 \%) \text {, diarrhea } \\
(25 \%) \text {, leukopenia }(22 \%) \text {, anemia } \\
(13 \%) \text {, and acne }(13 \%) .\end{array}$ \\
\hline $\begin{array}{l}\text { Weroha } \\
\text { et al. }[77] \\
\text { No. } 18\end{array}$ & $\begin{array}{l}\text { Recurrent/platinum-resistant } \\
\text { EOC/PPC; had previously } \\
\text { received first-line } \\
\text { platinum/taxane } \\
\text { treatment only }\end{array}$ & $\begin{array}{c}\text { Topotecan } 3.2 \mathrm{mg} / \mathrm{m}^{2} \mathrm{IV} \\
\text { on day } 1,8 \text { and } 15 \text { and } \\
\text { lapatinib } 1250 \mathrm{mg} \text { daily, } \\
\text { continuously in } 28 \text { day } \\
\text { cycles. PO }\end{array}$ & NR & NR & 3.5 months & 15.5 months & $\begin{array}{l}\text { Neutropenia }(56 \%), \\
\text { Thrombocytopenia }(28 \%), \\
\text { and diarrhea }(22 \%) .\end{array}$ \\
\hline
\end{tabular}




\begin{tabular}{|c|c|c|c|c|c|c|c|}
\hline $\begin{array}{l}\text { Makhija } \\
\text { et al. }[80] \\
\text { No. } 130\end{array}$ & $\begin{array}{l}\text { Recurrent EOC/PPC; had } \\
\text { previously received first-line } \\
\text { treatment }\end{array}$ & $\begin{array}{l}\text { gemcitabine plus either } \\
\text { pertuzumab or placebo }\end{array}$ & NR & NR & 2.9 months & 13.2 months & $\begin{array}{l}\text { Neutropenia }(39 \%), \\
\text { diarrhea }(11 \%) \text {, back pain }(9 \%) \\
\text { and } \mathrm{Fg}(22 \%)\end{array}$ \\
\hline $\begin{array}{l}\text { Bebakht } \\
\text { et al. }[81] \\
\text { No. } 60\end{array}$ & $\begin{array}{c}\text { Persistent/recurrent EOC/PPC } \\
\text { who had } \\
\text { received } 1 \text { - } 3 \\
\text { prior regimens }\end{array}$ & $\begin{array}{l}\text { Temsirolimus } 25 \mathrm{mg} \\
\text { weekly IV until } \\
\text { progression or } \\
\text { intolerable toxicity }\end{array}$ & NR & NR & 3.1 months & NR & $\begin{array}{l}\text { Metabolic ( } 8 \text { pts), } \\
\text { GI ( } 8 \text { pts }) \text {, pain ( } 6 \text { pts }) \text {, } \\
\text { and pulmonary ( } 4 \text { pts })\end{array}$ \\
\hline $\begin{array}{l}\text { Colombo et al. } \\
{[109]} \\
\text { No. } 16\end{array}$ & $\begin{array}{l}\text { Advanced chemo-resistant } \\
\text { EOC and symptomatic } \\
\text { malignant ascites }\end{array}$ & $\begin{array}{l}\text { Aflibercept } 4 \mathrm{mg} / \mathrm{kg} \text { every } \\
2 \text { weeks IV }\end{array}$ & NR & NR & 59.5 days & NR & $\begin{array}{l}\text { Hy and weight loss }(1 \mathrm{pt}) \\
\text { and intestinal perforation }(1 \mathrm{pt})\end{array}$ \\
\hline $\begin{array}{l}\text { Baumann } \\
\text { et al. }[114] \\
\text { No. } 73\end{array}$ & $\begin{array}{l}\text { recurrent platinum-resistant } \\
\text { ovarian cancer who were } \\
\text { pretreated with up to three } \\
\text { chemotherapies }\end{array}$ & $\begin{array}{l}\text { sunitinib (arm 1: } 50 \mathrm{mg} \text { daily } \\
\text { orally for } 28 \text { days followed by } \\
14 \text { days off drug; and arm } 2: \\
37.5 \mathrm{mg} \text { daily continuously }\end{array}$ & NR & NR & $\begin{array}{l}4.8 \text { months } \\
2.9 \text { months }\end{array}$ & $\begin{array}{l}13.6 \text { months } \\
13.7 \text { months }\end{array}$ & $\begin{array}{l}\text { cardiovascular, GI } \\
\text { and abdominal symptoms, } \\
\text { hematologic and hepatic labora- } \\
\text { tory abnormalities }\end{array}$ \\
\hline $\begin{array}{l}\text { Biagi } \\
\text { et al. }[115] \\
\text { No. } 30\end{array}$ & $\begin{array}{l}\text { measurable disease and one or } \\
\text { two prior chemotherapies, at } \\
\text { least one platinum based. } \\
\text { Platinum-sensitiveor resistant } \\
\text { disease was allowed. }\end{array}$ & $\begin{array}{l}50 \mathrm{mg} \text { daily, } 4 \text { of } 6 \text { weeks } \\
37.5 \mathrm{mg} \text { daily continuously }\end{array}$ & NR & NR & NR & 4.1 months & $\begin{array}{c}\text { Fg ( } 3 \text { pts }), \text { GI symptoms ( } 4 \text { pts }), \\
\text { HFS ( } 3 \text { pts }) \text { and Hp ( } 1 \text { pt }) .\end{array}$ \\
\hline
\end{tabular}

Abbreviations: RR, response rate; SD, stable disease; PFS, progression-free survival; OS, overall survival; NR, not reported; EOC, epithelial ovarian carcinoma; PSC, peritoneal serous carcinoma; PPC, primary peritoneal cancer; FTC, fallopian tube cancer; CT, chemotherapy; IV, intravenously; PO, oral dose; AUC, area under the concentration-time curve; AEs, adverse events; GI, gastrointestinal; Hp, hypertension; PSN, peripheral sensory neuropathy; HFS, hand-foot syndrome; Fg, fatigue. ${ }^{a} \mathrm{CT}$ options (investigator's choice): Paclitaxel (P) $80 \mathrm{mg} / \mathrm{m}^{2}$ days $1,8,15, \& 22 \mathrm{q} 4 \mathrm{w}$; Topotecan (T) $4 \mathrm{mg} / \mathrm{m}^{2} \mathrm{days} 1,8, \& 15 \mathrm{q} 4 \mathrm{w}\left(\right.$ or $1.25 \mathrm{mg} / \mathrm{m}^{2}$, days 1 - $5 \mathrm{q} 3 \mathrm{w}$ ); pegylated liposomal doxorubicin (PLD) $40 \mathrm{mg} / \mathrm{m}^{2}$ day $1 \mathrm{q} 4 \mathrm{w}$.

only may be a promising therapeutic option.

It could be interest to achieve additional information on the role of miRNAs as predictive factors of outcome and/or as new therapeutic agents. Further studies are eagerly awaited to disclose the real potential of both miRNA and miRNA inhibitors as new drugs to translate into clinical practice.

\section{REFERENCES}

[1] J. Ferlay, et al., "Estimates of Worldwide Burden of Cancer in 2008: GLOBOCAN 2008," International Journal of Cancer, Vol. 127, No. 12, 2010, pp. 2893-2917. doi:10.1002/ijc. 25516

[2] R. Siegel, et al., "Cancer Treatment and Survivorship Statistics, 2012," CA-A Cancer Journal for Clinicians, Vol. 62, No. 4, 2012, pp. 220-241. doi:10.3322/caac. 21149

[3] J. K. Chan, et al., "Patterns and Progress in Ovarian Cancer over 14 Years," Obstetrics \& Gynecology, Vol. 108, No. 3, 2006, pp. 521-528. doi:10.1097/01.AOG.0000231680.58221.a7

[4] R. C. Bast Jr., B. Hennessy and G. B. Mills, "The Biology of Ovarian Cancer: New Opportunities for Translation," Nature Reviews Cancer, Vol. 9, No. 6, 2009, pp. 415-428.

\section{doi:10.1038/nrc2644}

[5] R. Vang, M. Shih Ie and R. J. Kurman, "Ovarian LowGrade and High-Grade Serous Carcinoma: Pathogenesis, Clinicopathologic and Molecular Biologic Features, and Diagnostic Problems," Advances in Anatomic Pathology, Vol. 16, No. 5, 2009, pp. 267-282. doi:10.1097/PAP.0b013e3181b4fffa

[6] D. D. Bowtell, "The Genesis and Evolution of HighGrade Serous Ovarian Cancer," Nature Reviews Cancer, Vol. 10, No. 11, 2010, pp. 803-808. doi:10.1038/nrc2946

[7] N. Colombo, et al., "Newly Diagnosed and Relapsed Epithelial Ovarian Carcinoma: ESMO Clinical Practice Guidelines for Diagnosis, Treatment and Follow-Up," Annals of Oncology, Vol. 21, Supplement 5, 2010, pp. v23-v30. doi:10.1093/annonc/mdq244

[8] Cancer Genome Atlas Research Network, "Integrated Genomic Analyses of Ovarian Carcinoma," Nature, Vol. 474, No. 7353, 2011, pp. 609-615. doi:10.1038/nature10166

[9] P. Tagliaferri, et al., "BRCA1/2 Genetic BackgroundBased Therapeutic Tailoring of Human Ovarian Cancer: Hope or Reality?" Journal of Ovarian Research, Vol. 2, 2009, p. 14. doi:10.1186/1757-2215-2-14

[10] P. Tassone, et al., "Loss of BRCA1 Function Increases the Antitumor Activity of Cisplatin against Human Breast 
Cancer Xenografts in Vivo," Cancer Biology \& Therapy, Vol. 8, No. 7, 2009, pp. 648-653. doi:10.4161/cbt.8.7.7968

[11] P. Tassone, et al., "Differential Sensitivity of BRCA1Mutated HCC1937 Human Breast Cancer Cells to Microtubule-Interfering Agents," International Journal of Oncology, Vol. 26, No. 5, 2005, pp. 1257-1263.

[12] P. Tassone, et al., "BRCA1 Expression Modulates Chemosensitivity of BRCA1-Defective HCC1937 Human Breast Cancer Cells," British Journal of Cancer, Vol. 88, No. 8, 2003, pp. 1285-1291. doi:10.1038/sj.bjc.6600859

[13] F. Baudi, et al., "Evidence of a Founder Mutation of BRCA1 in a Highly Homogeneous Population from Southern Italy with Breast/Ovarian Cancer," Human Mutation, Vol. 18, No. 2, 2001, pp. 163-164.

doi:10.1002/humu. 1167

[14] "Cyclophosphamide Plus Cisplatin versus Cyclophosphamide, Doxorubicin, and Cisplatin Chemotherapy of Ovarian Carcinoma: A Meta-Analysis. The Ovarian Cancer Meta-Analysis Project," Journal of Clinical Oncology, Vol. 9, No. 9, 1991, pp. 1668-1674.

[15] M. A. Bookman, B. E. Greer and R. F. Ozols, "Optimal Therapy of Advanced Ovarian Cancer: Carboplatin and Paclitaxel vs. Cisplatin and Paclitaxel (GOG 158) and an Update on GOG0 182-ICON5," International Journal of Gynecological Cancer, Vol. 13, No. 6, 2003, pp. 735740. doi:10.1111/j.1525-1438.2003.13602.x

[16] R. F. Ozols, et al., "Phase III Trial of Carboplatin and Paclitaxel Compared with Cisplatin and Paclitaxel in Patients with Optimally Resected Stage III Ovarian Cancer: A Gynecologic Oncology Group Study," Journal of Clinical Oncology, Vol. 21, No. 17, 2003, pp. 3194-3200. doi:10.1200/JCO.2003.02.153

[17] R. A. Burger, et al., "Incorporation of Bevacizumab in the Primary Treatment of Ovarian Cancer," The New England Journal of Medicine, Vol. 365, No. 26, 2011, pp. 24732483. doi:10.1056/NEJMoa1104390

[18] J. A. Ledermann and R. S. Kristeleit, "Optimal Treatment for Relapsing Ovarian Cancer," Annals of Oncology, Vol. 21, Supplement 7, 2010, pp. vii218-vii222. doi:10.1093/annonc/mdq377

[19] M. Fung-Kee-Fung, et al., "Optimal Chemotherapy Treatment for Women with Recurrent Ovarian Cancer," Current Oncology, Vol. 14, No. 5, 2007, pp. 195-208. doi: $10.3747 /$ co. 2007.148

[20] I. A. Cree, et al., "A Prospective Randomized Controlled Trial of Tumour Chemosensitivity Assay Directed Chemotherapy Versus Physician's Choice in Patients with Recurrent Platinum-Resistant Ovarian Cancer," Anticancer Drugs, Vol. 18, No. 9, 2007, pp. 1093-1101. doi:10.1097/CAD.0b013e3281de727e

[21] J. A. Ledermann and F. A. Raja, "Clinical Trials and Decision-Making Strategies for Optimal Treatment of Relapsed Ovarian Cancer," European Journal of Cancer, Vol. 47, Supplement 3, 2011, pp. S104-S115. doi:10.1016/S0959-8049(11)70154-X

[22] A. N. Gordon, et al., "Long-Term Survival Advantage for
Women Treated with Pegylated Liposomal Doxorubicin Compared with Topotecan in a Phase 3 Randomized Study of Recurrent and Refractory Epithelial Ovarian Cancer," Gynecologic Oncology, Vol. 95, No. 1, 2004, pp. 1-8. doi:10.1016/j.ygyno.2004.07.011

[23] V. Adamo, et al., "Pegylated Liposomal Doxorubicin and Gemcitabine in the Front-Line Treatment of Recurrent/ Metastatic Breast Cancer: A Multicentre Phase II Study," British Journal of Cancer, Vol. 98, No. 12, 2008, pp. 1916-1921. doi:10.1038/sj.bjc.6604409

[24] G. Ferrandina, et al., "Phase III Trial of Gemcitabine Compared with Pegylated Liposomal Doxorubicin in Progressive or Recurrent Ovarian Cancer," Journal of Clinical Oncology, Vol. 26, No. 6, 2008, pp. 890-896. doi:10.1200/JCO.2007.13.6606

[25] D. G. Mutch, et al., "Randomized Phase III Trial of Gemcitabine Compared with Pegylated Liposomal Doxorubicin in Patients with Platinum-Resistant Ovarian Cancer," Journal of Clinical Oncology, Vol. 25, No. 19, 2007, pp. 2811-2818. doi:10.1200/JCO.2006.09.6735

[26] B. Lund and J. P. Neijt, "Gemcitabine in Cisplatin-Resistant Ovarian Cancer," Seminars in Oncology, Vol. 23, No. 5, 1996, pp. 72-76.

[27] B. Lund, et al., 'Phase II Study of Gemcitabine (2',2'Difluorodeoxycytidine) in Previously Treated Ovarian Cancer Patients," Journal of the National Cancer Institute, Vol. 86, No. 20, 1994, pp. 1530-1533. doi:10.1093/jnci/86.20.1530

[28] G. D'Agostino, M. Ceccaroni and G. Scambia, "Gemcitabine, Ovarian Cancer, and the Elderly," International Journal of Gynecological Cancer, Vol. 15, No. 1, 2005, pp. 180-181. doi:10.1111/j.1048-891X.2005.15005.X

[29] E. Fruscella, et al., "Gemcitabine: Current Role and Future Options in the Treatment of Ovarian Cancer," Critical Reviews in Oncology/Hematology, Vol. 48, No. 1, 2003, pp. 81-88. doi:10.1016/S1040-8428(03)00119-7

[30] G. D'Agostino, et al., "Phase II Study of Gemcitabine in Recurrent Platinum-and Paclitaxel-Resistant Ovarian Cancer," Gynecologic Oncology, Vol. 88, No. 3, 2003, pp. 266-269. doi:10.1016/S1040-8428(03)00119-7

[31] N. Staropoli, et al., "A Retrospective Analysis of Pegylated Liposomal Doxorubicin in Ovarian Cancer: Do We Still Need It?" Journal of Ovarian Research, Vol. 6, No. 1, 2013, p. 10. doi:10.1186/1757-2215-6-10

[32] D. Lorusso, et al., "Role of Gemcitabine in Ovarian Cancer Treatment," Annals of Oncology, Vol. 17, Supplement 5, 2006, pp. v188-v194. doi:10.1093/annonc/mdj979

[33] D. Lorusso, et al., "Gemcitabine in Epithelial Ovarian Cancer Treatment: Current Role and Future Perspectives," International Journal of Gynecological Cancer, Vol. 15, No. 6, 2005, pp. 1002-1013. doi:10.1111/j.1525-1438.2005.00331.x

[34] F. Tomao, et al., "Emerging Role of Pemetrexed in Ovarian Cancer," Expert Review of Anticancer Therapy, Vol. 9, No. 12, 2009, pp. 1727-1735. doi:10.1586/era.09.141

[35] I. Vergote, et al., "A Randomised, Double-Blind, Phase II Study of Two Doses of Pemetrexed in the Treatment of 
Platinum-Resistant, Epithelial Ovarian or Primary Peritoneal Cancer," European Journal of Cancer, Vol. 45, No. 8, 2009, pp. 1415-1423. doi:10.1016/j.ejca.2008.12.013

[36] D. S. Miller, et al., "Phase II Evaluation of Pemetrexed in the Treatment of Recurrent or Persistent Platinum-Resistant Ovarian or Primary Peritoneal Carcinoma: A Study of the Gynecologic Oncology Group," Journal of Clinical Oncology, Vol. 27, No. 16, 2009, pp. 2686-2691. doi:10.1200/JCO.2008.19.2963

[37] P. G. Rose, et al., "Prolonged Oral Etoposide as SecondLine Therapy for Platinum-Resistant and Platinum-Sensitive Ovarian Carcinoma: A Gynecologic Oncology Group Study," Journal of Clinical Oncology, Vol. 16, No. 2, 1998, pp. 405-410.

[38] M. Markman, et al., "Phase II Trial of Weekly Paclitaxel $(80 \mathrm{mg} / \mathrm{m} 2)$ in Platinum and Paclitaxel-Resistant Ovarian and Primary Peritoneal Cancers: A Gynecologic Oncology Group Study," Gynecologic Oncology, Vol. 101, No. 3, 2006, pp. 436-440. doi:10.1016/j.ygyno.2005.10.036

[39] M. Markman, et al., "Phase II Trial of Weekly SingleAgent Paclitaxel in Platinum/Paclitaxel-Refractory Ovarian Cancer," Journal of Clinical Oncology, Vol. 20, No. 9, 2002, pp. 2365-2369. doi:10.1200/JCO.2002.09.130

[40] R. L. Coleman, et al., "A Phase II Evaluation of Nanoparticle, Albumin-Bound (Nab) Paclitaxel in the Treatment of Recurrent or Persistent Platinum-Resistant Ovarian, Fallopian Tube, or Primary Peritoneal Cancer: A Gynecologic Oncology Group Study," Gynecologic Oncology, Vol. 122, No. 1, 2011, pp. 111-115. doi:10.1016/j.ygyno.2011.03.036

[41] P. G. Rose, et al., "A Phase II Study of Docetaxel in Paclitaxel-Resistant Ovarian and Peritoneal Carcinoma: A Gynecologic Oncology Group Study," Gynecologic Oncology, Vol. 88, No. 2, 2003, pp. 130-135. doi:10.1016/S0090-8258(02)00091-4

[42] A. Polyzos, et al., "Docetaxel in Combination with Irinotecan (CPT-11) in Platinum-Resistant Paclitaxel-Pretreated Ovarian Cancer," Anticancer Research, Vol. 25, No. 5, 2005, pp. 3559-3564.

[43] G. Bolis, et al., "Paclitaxel vs Epidoxorubicin Plus Paclitaxel as Second-Line Therapy for Platinum-Refractory and -Resistant Ovarian Cancer," Gynecologic Oncology, Vol. 72, No. 1, 1999, pp. 60-64. doi:10.1006/gyno.1998.5237

[44] A. Buda, et al., "Randomised Controlled Trial Comparing Single Agent Paclitaxel vs Epidoxorubicin Plus Paclitaxel in Patients with Advanced Ovarian Cancer in Early Progression after Platinum-Based Chemotherapy: An Italian Collaborative Study from the Mario Negri Institute, Milan, G.O.N.O. (Gruppo Oncologico Nord Ovest) Group and I.O.R. (Istituto Oncologico Romagnolo) Group," British Journal of Cancer, Vol. 90, No. 11, 2004, pp. 21122117.

[45] M. G. Cantu, et al., "Randomized Controlled Trial of Single-Agent Paclitaxel versus Cyclophosphamide, Doxorubicin, and Cisplatin in Patients with Recurrent Ovarian Cancer Who Responded to First-Line Platinum-Based Regimens," Journal of Clinical Oncology, Vol. 20, No. 5, 2002, pp. 1232-1237. doi:10.1200/JCO.20.5.1232
[46] V. Torri, et al., "Paclitaxel and Cisplatin in Ovarian Cancer," Journal of Clinical Oncology, Vol. 18, No. 11, 2000, pp. 2349-2351.

[47] J. Sehouli, et al., "Nonplatinum Topotecan Combinations versus Topotecan alone for Recurrent Ovarian Cancer: Results of a Phase III Study of the North-Eastern German Society of Gynecological Oncology Ovarian Cancer Study Groupp," Journal of Clinical Oncology, Vol. 26, No. 19, 2008, pp. 3176-3182. doi:10.1200/JCO.2007.15.1258

[48] B. J. Monk, et al., "Trabectedin Plus Pegylated Liposomal Doxorubicin (PLD) versus PLD in Recurrent Ovarian Cancer: Overall Survival Analysis," European Journal of Cancer, Vol. 48, No. 15, 2012, pp. 2361-2368. doi:10.1016/i.ejca.2012.04.001

[49] B. J. Monk, et al., "Trabectedin Plus Pegylated Liposomal Doxorubicin in Recurrent Ovarian Cancer," Journal of Clinical Oncology, Vol. 28, No. 19, 2010, pp. 3107-3114. doi:10.1200/JCO.2009.25.4037

[50] A. Lortholary, et al., "Weekly Paclitaxel as a Single Agent or in Combination with Carboplatin or Weekly Topotecan in Patients with Resistant Ovarian Cancer: The CARTAXHY Randomized Phase II Trial from Groupe d'Investigateurs Nationaux Pour l'Etude des Cancers Ovariens (GINECO)," Annals Oncology, Vol. 23, No. 2, 2012, pp. 346-352. doi:10.1093/annonc/mdr149

[51] E. Pujade-Lauraine and J. Alexandre, "Update of Randomized Trials in Recurrent Disease," Annals Oncology, Vol. 22, Suppl. 8, 2011, pp. viii61-viii64.

[52] I. Ray-Coquard, et al., "Gemcitabine-Oxaliplatin Combination for Ovarian Cancer Resistant to Taxane-Platinum Treatment: A Phase II Study from the GINECO Group," British Journal of Cancer, Vol. 100, 2009, pp. 601-607. doi:10.1038/sj.bjc. 6604878

[53] P. P. Harnett, et al., "Phase II Study of Gemcitabine and Oxaliplatin in Patients with Recurrent Ovarian Cancer: An Australian and New Zealand Gynaecological Oncology Group Study," International Journal of Gynecological Cancer, Vol. 17, No. 2, 2007. pp. 359-366. doi:10.1111/j.1525-1438.2007.00763.x

[54] N. Colombo, et al., "Randomized, Open-Label, Phase III Study Comparing Patupilone (EPO906) with Pegylated Liposomal Doxorubicin in Platinum-Refractory or -Resistant Patients with Recurrent Epithelial Ovarian, Primary Fallopian Tube, or Primary Peritoneal Cancer," Journal of Clinical Oncology, Vol. 30, No. 31, 2012, pp. 38413847. doi:10.1200/JCO.2011.38.8082

[55] I. Vergote, et al., "Randomized Phase III Study of Canfosfamide in Combination with Pegylated Liposomal Doxorubicin Compared with Pegylated Liposomal Doxorubicin alone in Platinum-Resistant Ovarian Cancer," International Journal of Gynecological Cancer, Vol. 20, No. 5, 2010, pp. 772-780. doi:10.1111/IGC.0b013e3181daaf59

[56] J. J. Kavanagh, et al., "Phase 2 Study of Canfosfamide in Combination with Pegylated Liposomal Doxorubicin in Platinum and Paclitaxel Refractory or Resistant Epithelial Ovarian Cancer," Journal of Hematology Oncology, Vol. 3, 2010, p. 9. doi:10.1186/1756-8722-3-9

[57] L. V. Sequist, et al., "Phase 1-2a Multicenter Dose-Ran- 
ging Study of Canfosfamide in Combination with Carboplatin and Paclitaxel as First-Line Therapy for Patients with Advanced Non-Small Cell Lung Cancer," Journal of Thoracic Oncology, Vol. 4, No. 11, 2009, pp. 1389-1396. doi:10.1097/JTO.0b013e3181b6b84b

[58] I. Vergote, et al., "Phase 3 Randomised Study of Canfosfamide (Telcyta, TLK286) versus Pegylated Liposomal Doxorubicin or Topotecan as Third-Line Therapy in Patients with Platinum-Refractory or -Resistant Ovarian Cancer," European Journal of Cancer, Vol. 45, No. 13, 2009, pp. 2324-2332. doi:10.1016/j.ejca.2009.05.016

[59] S. A. Cannistra, et al., "Phase II Study of Bevacizumab in Patients with Platinum-Resistant Ovarian Cancer or Peritoneal Serous Cancer," Journal Clinical Oncology, Vol. 25, No. 33, 2007, pp. 5180-5186. doi:10.1200/JCO.2007.12.0782

[60] E. Pujade-Lauraine, et al., "AURELIA: A Randomized Phase III Trial Evaluating Bevacizumab (BEV) Plus Chemotherapy (CT) for Platinum (PT)-Resistant Recurrent Ovarian Cancer (OC)," ASCO Meeting Abstracts, Vol. 30, Supplement 18, 2012, p. LBA5002.

[61] M. Eichbaum, et al., "The PACOVAR-Trial: A Phase I/II Study of Pazopanib (GW786034) and Cyclophosphamide in Patients with Platinum-Resistant Recurrent, Pre-treated Ovarian Cancer," BMC Cancer, Vol. 11, 2011, p. 453. doi:10.1186/1471-2407-11-453

[62] M. Friedlander, et al., "A Phase II, Open-Label Study Evaluating Pazopanib in Patients with Recurrent Ovarian Cancer," Gynecologic Oncology, Vol. 119, No. 1, 2010, pp. 32-37. doi:10.1016/j.ygyno.2010.05.033

[63] K. Hashimoto, et al., "Potent Preclinical Impact of Metronomic Low-Dose Oral Topotecan Combined with the Antiangiogenic Drug Pazopanib for the Treatment of Ovarian Cancer," Molecular Cancer Therapeutics, Vol. 9, No. 4, 2010, pp. 996-1006.

doi:10.1158/1535-7163.MCT-09-0960

[64] C. L. Arteaga, "Overview of Epidermal Growth Factor Receptor Biology and Its Role as a Therapeutic Target in Human Neoplasia," Seminars in Oncology, Vol. 29, No. 5, 2002, pp. 3-9. doi:10.1016/S0093-7754(02)70085-7

[65] M. Cross and T. M. Dexter, "Growth Factors in Development, Transformation, and Tumorigenesis," Cell, Vol. 64, No. 2, 1991, pp. 271-280. doi:10.1016/0092-8674(91)90638-F

[66] Y. Yarden and M. X. Sliwkowski, "Untangling the ErbB Signalling Network," Nature Reviews Molecular Cell Biology, Vol. 2, No. 2, 2001, pp. 127-137. doi: $10.1038 / 35052073$

[67] R. Buettner, L. B. Mora and R. Jove, "Activated STAT Signaling in Human Tumors Provides Novel Molecular Targets for Therapeutic Intervention," Clinical Cancer Research, Vol. 8, No. 4, 2002, pp. 945-954.

[68] J. Harding and B. Burtness, "Cetuximab: An Epidermal Growth Factor Receptor Chimeric Human-Murine Monoclonal Antibody," Drugs Today (Barc), Vol. 41, No. 2, 2005, pp. 107-127. doi:10.1358/dot.2005.41.2.882662

[69] R. J. Schilder, et al., "Phase II Trial of Single Agent Cetuximab in Patients with Persistent or Recurrent Epithelial
Ovarian or Primary Peritoneal Carcinoma with the Potential for Dose Escalation to Rash," Gynecologic Oncology, Vol. 113, No. 1, 2009, pp. 21-27.

doi:10.1016/j.ygyno.2008.12.003

[70] M. V. Seiden, et al., "A Phase II Trial of EMD72000 (Matuzumab), a Humanized Anti-EGFR Monoclonal Antibody, in Patients with Platinum-Resistant Ovarian and Primary Peritoneal Malignancies," Gynecologic Oncology, Vol. 104, No. 3, 2007, pp. 727-731. doi:10.1016/j.ygyno.2006.10.019

[71] A. N. Gordon, et al., "Efficacy and Safety of Erlotinib $\mathrm{HCl}$, an Epidermal Growth Factor Receptor (HER1/ EGFR) Tyrosine Kinase Inhibitor, in Patients with Advanced Ovarian Carcinoma: Results from a Phase II Multicenter Study," International Journal of Gynecological Cancer, Vol. 15, No. 5, 2005, pp. 785-792. doi:10.1111/j.1525-1438.2005.00137.x

[72] R. J. Schilder, et al., "Phase II Study of Gefitinib in Patients with Relapsed or Persistent Ovarian or Primary Peritoneal Carcinoma and Evaluation of Epidermal Growth Factor Receptor Mutations and Immunohistochemical Expression: A Gynecologic Oncology Group Study," Clinical Cancer Research, Vol. 11, No. 15, 2005, pp. 55395548. doi:10.1158/1078-0432.CCR-05-0462

[73] U. Wagner, et al., "Gefitinib in Combination with Tamoxifen in Patients with Ovarian Cancer Refractory or Resistant to Platinum-Taxane Based Therapy-A Phase II Trial of the AGO Ovarian Cancer Study Group (AGOOVAR 2.6)," Gynecologic Oncology, Vol. 105, No. 1, 2007, pp. 132-137. doi:10.1016/j.ygyno.2006.10.053

[74] P. P. Pautier, et al., "Phase II Study of Gefitinib in Combination with Paclitaxel (P) and Carboplatin (C) as Second-Line Therapy for Ovarian, Tubal or Peritoneal Adenocarcinoma (1839IL/0074)," Gynecologic Oncology, Vol. 116, No. 2, 2010, pp. 157-162. doi:10.1016/j.ygyno.2009.10.076

[75] M. A. Bookman, et al., "Evaluation of Monoclonal Humanized Anti-HER2 Antibody, Trastuzumab, in Patients with Recurrent or Refractory Ovarian or Primary Peritoneal Carcinoma with Overexpression of HER2: A Phase II Trial of the Gynecologic Oncology Group," Journal of Clinical Oncology, Vol. 21, No. 2, 2003, pp. 283-290. doi:10.1200/JCO.2003.10.104

[76] S. Campos, et al., "Multicenter, Randomized Phase II Trial of Oral CI-1033 for Previously Treated Advanced Ovarian Cancer," Journal of Clinical Oncology, Vol. 23, No. 24, 2005, pp. 5597-5604.

doi:10.1200/JCO.2005.08.091

[77] S. J. Weroha, et al., "Phase II Trial of Lapatinib and Topotecan (LapTop) in Patients with Platinum-Refractory/ Resistant Ovarian and Primary Peritoneal Carcinoma," Gynecologic Oncology, Vol. 122, No. 1, 2011, pp. 116120. doi:10.1016/j.ygyno.2011.03.030

[78] A. A. Garcia, et al., "A Phase II Evaluation of Lapatinib in the Treatment of Persistent or Recurrent Epithelial Ovarian or Primary Peritoneal Carcinoma: A Gynecologic Oncology Group Study," Gynecologic Oncology, Vol. 124, No. 3, 2012, pp. 569-574. doi:10.1016/j.ygyno.2011.10.022 
[79] M. C. Franklin, et al., "Insights into ErbB Signaling from the Structure of the ErbB2-Pertuzumab Complex," Cancer Cell, Vol. 5, No. 4, 2004, pp. 317-328. doi:10.1016/S1535-6108(04)00083-2

[80] S. Makhija, et al., "Clinical Activity of Gemcitabine Plus Pertuzumab in Platinum-Resistant Ovarian Cancer, Fallopian Tube Cancer, or Primary Peritoneal Cancer," Journal of Clinical Oncology, Vol. 28, No. 7, 2010, pp. 12151223. doi:10.1200/JCO.2009.22.3354

[81] K. Behbakht, et al., "Phase II Trial of the mTOR Inhibitor, Temsirolimus and Evaluation of Circulating Tumor Cells and Tumor Biomarkers in Persistent and Recurrent Epithelial Ovarian and Primary Peritoneal Malignancies: A Gynecologic Oncology Group Study," Gynecologic Oncology, Vol. 123, No. 1, 2011, pp. 19-26. doi:10.1016/j.ygyno.2011.06.022

[82] S. B. Kaye, et al., "Phase II, Open-Label, Randomized, Multicenter Study Comparing the Efficacy and Safety of Olaparib, a Poly (ADP-Ribose) Polymerase Inhibitor, and Pegylated Liposomal Doxorubicin in Patients with BRCA1 or BRCA2 Mutations and Recurrent Ovarian Cancer," Journal of Clinical Oncology, Vol. 30, No. 4, 2012, pp. 372-379. doi:10.1200/JCO.2011.36.9215

[83] A. Maccio and C. Madeddu, "Inflammation and Ovarian Cancer," Cytokine, Vol. 58, No. 2, 2012, pp. 133-147. doi:10.1016/i.cyto.2012.01.015

[84] C. C. Preston, et al., "Immunity and Immune Suppression in Human Ovarian Cancer," Immunotherapy, Vol. 3, No. 4, 2011, pp. 539-556. doi:10.2217/imt.11.20

[85] G. Ferrandina, et al., "Cyclooxygenase-2 (COX-2), Epidermal Growth Factor Receptor (EGFR), and Her-2/Neu Expression in Ovarian Cancer," Gynecologic Oncology, Vol. 85, No. 2, 2002, pp. 305-310. doi:10.1006/gyno.2002.6620

[86] R. Ali-Fehmi, et al., "Molecular Typing of Epithelial Ovarian Carcinomas Using Inflammatory Markers," Cancer, Vol. 117, No. 2, 2011, pp. 301-309. doi:10.1002/cncr.25588

[87] Y. Wang, et al., "Autocrine Production of Interleukin-6 Confers Cisplatin and Paclitaxel Resistance in Ovarian Cancer Cells," Cancer Letters, Vol. 295, No. 1, 2010. pp. 110-123. doi:10.1016/j.canlet.2010.02.019

[88] M. S. Anglesio, et al., "Clear Cell Carcinoma of the Ovary: A Report from the First Ovarian Clear Cell Symposium, June 24th, 2010," Gynecologic Oncology, Vol. 121, No. 2, 2011, pp. 407-415. doi:10.1016/j.ygyno.2011.01.005

[89] M. S. Anglesio, et al., "IL6-STAT3-HIF Signaling and Therapeutic Response to the Angiogenesis Inhibitor Sunitinib in Ovarian Clear Cell Cancer," Clinical Cancer Research, Vol. 17, No. 8, 2011, pp. 2538-2548. doi:10.1158/1078-0432.CCR-10-3314

[90] N. Pore, et al., "EGFR Tyrosine Kinase Inhibitors Decrease VEGF Expression by Both Hypoxia-Inducible Factor (HIF)-1-Independent and HIF-1-Dependent Mechanisms," Cancer Research, Vol. 66, No. 6, 2006, pp. 3197 3204. doi:10.1158/0008-5472.CAN-05-3090

[91] D. Herr, et al., "VEGF Induces Ascites in Ovarian Cancer
Patients via Increasing Peritoneal Permeability by Downregulation of Claudin 5," Gynecologic Oncology, Vol. 127, No. 1,2012 , pp. $210-216$. doi:10.1016/j.ygyno.2012.05.002

[92] J. E. Ohm, et al., "VEGF Inhibits T-Cell Development and May Contribute to Tumor-Induced Immune Suppression," Blood, Vol. 101, No. 12, 2003, pp. 4878-4886. doi:10.1182/blood-2002-07-1956

[93] M. Della Porta, et al., "Dendritic Cells and Vascular Endothelial Growth Factor in Colorectal Cancer: Correlations with Clinicobiological Findings," Oncology, Vol. 68, No. 2-3, 2005, pp. 276-284. doi:10.1159/000086784

[94] A. Bamias, et al., "Correlation of NK T-Like CD3+ CD56+ Cells and CD4+CD25+(hi) Regulatory T Cells with VEGF and TNFalpha in Ascites from Advanced Ovarian Cancer: Association with Platinum Resistance and Prognosis in Patients Receiving First-Line, PlatinumBased Chemotherapy," Gynecologic Oncology, Vol. 108, No. 2, 2008, pp. 421-427.

doi:10.1016/j.ygyno.2007.10.018

[95] P. P. Allavena, et al., "Pathways Connecting Inflammation and Cancer," Current Opinion in Genetics \& Development, Vol. 18, No. 1, 2008, pp. 3-10. doi:10.1016/j.gde.2008.01.003

[96] P. P. Correale, et al., "Tumor Infiltration by Chemokine Receptor 7 (CCR7) ${ }^{+}$T-Lymphocytes Is a Favorable Prognostic Factor in Metastatic Colorectal Cancer," Oncoimmunology, Vol. 1, No. 4, 2012, pp. 531-532. doi:10.4161/onci.19404

[97] P. P. Correale, et al., "Tumor Infiltration by T Lymphocytes Expressing Chemokine Receptor 7 (CCR7) Is Predictive of Favorable Outcome in Patients with Advanced Colorectal Carcinoma," Clinical Cancer Research, Vol. 18 , No. 3, 2012, pp. 850-857. doi:10.1158/1078-0432.CCR-10-3186

[98] P. P. Correale, et al., "Regulatory (FoxP3+) T-Cell Tumor Infiltration Is a Favorable Prognostic Factor in Advanced Colon Cancer Patients Undergoing Chemo or Chemoimmunotherapy," Journal of Immunotherapy, Vol. 33, No. 4, 2010, pp. 435-441. doi:10.1097/CJI.0b013e3181d32f01

[99] G. Solinas, et al., "Tumor-Associated Macrophages (TAM) as Major Players of the Cancer-Related Inflammation," Journal of Leukocyte Biology, Vol. 86, No. 5, 2009, pp. 1065-1073. doi:10.1189/jlb.0609385

[100] M. Petrillo, G. Scambia and G. Ferrandina, "Novel Targets for VEGF-Independent Anti-Angiogenic Drugs," $E x$ pert Opinion Investigational Drugs, Vol. 21, No. 4, 2012, pp. 451-472. doi:10.1517/13543784.2012.661715

[101] C. Aghajanian, et al., "OCEANS: A Randomized, Double-Blind, Placebo-Controlled Phase III Trial of Chemotherapy with or without Bevacizumab in Patients with Platinum-Sensitive Recurrent Epithelial Ovarian, Primary Peritoneal, or Fallopian Tube Cancer," Journal of Clinical Oncology, Vol. 30, No. 17, 2012, pp. 2039-2045. doi:10.1200/JCO.2012.42.0505

[102] R. A. Burger, et al., "Phase II Trial of Bevacizumab in Persistent or Recurrent Epithelial Ovarian Cancer or Pri- 
mary Peritoneal Cancer: A Gynecologic Oncology Group Study," Journal of Clinical Oncology, Vol. 25, No. 33, 2007, pp. 5165-5171. doi:10.1200/JCO.2007.11.5345

[103] R. Wild, et al., "Carboplatin Selectively Induces the VEGF Stress Response in Endothelial Cells: Potentiation of Antitumor Activity by Combination Treatment with Antibody to VEGF," International Journal of Cancer, Vol. 110, No. 3, 2004, pp. 343-351.

doi:10.1002/ijc. 20100

[104] R. K. Jain, "Normalization of Tumor Vasculature: An Emerging Concept in Antiangiogenic Therapy," Science, Vol. 307, No. 5706, 2005, pp. 58-62.

doi:10.1126/science.1104819

[105] A. A. Garcia, et al., "Phase II Clinical Trial of Bevacizumab and Low-Dose Metronomic Oral Cyclophosphamide in Recurrent Ovarian Cancer: A Trial of the California, Chicago, and Princess Margaret Hospital phase II Consortia," Journal of Clinical Oncology, Vol. 26, No. 1, 2008, pp. 76-82. doi:10.1200/JCO.2007.12.1939

[106] T. D. Tillmanns, et al., "Phase II Clinical Trial of Bevacizumab with Albumin-Bound Paclitaxel in Patients with Recurrent, Platinum-Resistant Primary Epithelial Ovarian or Primary Peritoneal Carcinoma," Gynecologic Oncology, Vol. 128, No. 2, 2013, pp. 221-228.

doi:10.1016/j.ygyno.2012.08.039

[107] A. T. Byrne, et al., "Vascular Endothelial Growth FactorTrap Decreases Tumor Burden, Inhibits Ascites, and Causes Dramatic Vascular Remodeling in an Ovarian Cancer Model," Clinical Cancer Research, Vol. 9, No. 15, 2003, pp. 5721-5728.

[108] W. H. Gotlieb, et al., "Intravenous Aflibercept for Treatment of Recurrent Symptomatic Malignant Ascites in Patients with Advanced Ovarian Cancer: A Phase 2, Randomised, Double-Blind, Placebo-Controlled Study," The Lancet Oncology, Vol. 13, No. 2, 2012, pp. 154-162. doi:10.1016/S1470-2045(11)70338-2

[109] N. Colombo, et al., "A Phase II Study of Aflibercept in Patients with Advanced Epithelial Ovarian Cancer and Symptomatic Malignant Ascites," Gynecologic Oncology, Vol. 125, No. 1, 2012, pp. 42-47. doi:10.1016/j.ygyno.2011.11.021

[110] E. M. Posadas, et al., "A Prospective Analysis of Imatinib-Induced c-KIT Modulation in Ovarian Cancer: A Phase II Clinical Study with Proteomic Profiling," Cancer, Vol. 110, No. 2, 2007, pp. 309-317. doi:10.1002/cncr.22757

[111] A. A. Secord, et al., "A Phase I Trial of Dasatinib, an SrcFamily Kinase Inhibitor, in Combination with Paclitaxel and Carboplatin in Patients with Advanced or Recurrent Ovarian Cancer," Clinical Cancer Research, Vol. 18, No. 19, 2012, pp. 5489-5498. doi:10.1158/1078-0432.CCR-12-0507

[112] L. Bodnar, M. Gornas and C. Szczylik, "Sorafenib as a Third Line Therapy in Patients with Epithelial Ovarian Cancer or Primary Peritoneal Cancer: A Phase II Study," Gynecologic Oncology, Vol. 123, No. 1, 2011, pp. 33-36. doi:10.1016/j.ygyno.2011.06.019

[113] D. Matei, et al., "Activity of Sorafenib in Recurrent Ovar- ian Cancer and Primary Peritoneal Carcinomatosis: A Gynecologic Oncology Group Trial," Journal of Clinical Oncology, Vol. 29, No. 1, 2011, pp. 69-75. doi:10.1200/jco.2009.26.7856

[114] K. H. Baumann, et al., "A Phase II Trial (AGO 2.11) in Platinum-Resistant Ovarian Cancer: A Randomized Multicenter Trial with Sunitinib (SU11248) to Evaluate Dosage, Schedule, Tolerability, Toxicity and Effectiveness of a Multitargeted Receptor Tyrosine Kinase Inhibitor Monotherapy," Annals of Oncology, Vol. 23, No. 9, 2012, pp. 2265-2271. doi:10.1093/annonc/mds003

[115] J. J. Biagi, et al., "A Phase II Study of Sunitinib in Patients with Recurrent Epithelial Ovarian and Primary Peritoneal Carcinoma: An NCIC Clinical Trials Group Study," Annals of Oncology, Vol. 22, No. 2, 2011, pp. 335340. doi:10.1093/annonc/mdq357

[116] F. A. Raja, et al., "Initial Toxicity Assessment of ICON6: A Randomised Trial of Cediranib Plus Chemotherapy in Platinum-Sensitive Relapsed Ovarian Cancer," British Journal of Cancer, Vol. 105, No. 7, 2011, pp. 884-889. doi:10.1038/bjc.2011.334

[117] U. A. Matulonis, et al., "Cediranib, an Oral Inhibitor of Vascular Endothelial Growth Factor Receptor Kinases, Is an Active Drug in Recurrent Epithelial Ovarian, Fallopian Tube, and Peritoneal Cancer," Journal of Clinical Oncology, Vol. 27, No. 33, 2009, pp. 5601-5606. doi:10.1200/JCO.2009.23.2777

[118] J. A. Ledermann, et al., "Randomized Phase II PlaceboControlled Trial of Maintenance Therapy Using the Oral Triple Angiokinase Inhibitor BIBF 1120 after Chemotherapy for Relapsed Ovarian Cancer," Journal of Clinical Oncology, Vol. 29, No. 28, 2011, pp. 3798-3804. doi:10.1200/JCO.2010.33.5208

[119] B. Y. Karlan, et al., "Randomized, Double-Blind, Placebo-Controlled Phase II Study of AMG 386 Combined with Weekly Paclitaxel in Patients with Recurrent Ovarian Cancer," Journal of Clinical Oncology, Vol. 30, No. 4, 2012, pp. 362-371. doi:10.1200/JCO.2010.34.3178

[120] M. S. Zaman, et al., "Current Status and Implications of MicroRNAs in Ovarian Cancer Diagnosis and Therapy," Journal of Ovarian Research, Vol. 5, No. 1, 2012, p. 44. doi:10.1186/1757-2215-5-44

[121] P. P. Tagliaferri, et al., "Promises and Challenges of MicroRNA-Based Treatment of Multiple Myeloma," Current Cancer Drug Targets, Vol. 12, No. 7, 2012, pp. 838846. doi:10.2174/156800912802429355

[122] E. Leone, et al., "Targeting miR-21 Inhibits In Vitro and In Vivo Multiple Myeloma Cell Growth," Clinical Cancer Research, Vol. 19, 2013, p. 2096. doi:10.1158/1078-0432.CCR-12-3325

[123] Y. Lou, et al., "miR-21 Down-Regulation Promotes Apoptosis and Inhibits Invasion and Migration Abilities of OVCAR3 Cells," Clinical \& Investigative Medicine, Vol. 34, No. 5, 2011, p. E281.

[124] S. C. Righetti, et al., "A Comparative Study of p53 Gene Mutations, Protein Accumulation, and Response to Cisplatin-Based Chemotherapy in Advanced Ovarian Carcinoma," Cancer Research, Vol. 56, No. 4, 1996, pp. 689- 
693.

[125] D. C. Corney, et al., "Frequent Downregulation of miR34 Family in Human Ovarian Cancers," Clinical Cancer Research, Vol. 16, No. 4, 2010, pp. 1119-1128. doi:10.1158/1078-0432.CCR-09-2642

[126] M. T. Di Martino, et al., "Synthetic miR-34a Mimics as a Novel Therapeutic Agent for Multiple Myeloma: In Vitro and In Vivo Evidence," Clinical Cancer Research, Vol. 18, No. 22, 2012, pp. 6260-6270. doi:10.1158/1078-0432.CCR-12-1708

[127] M. Rossi, et al., "miR-29b Negatively Regulates Human Osteoclastic Cell Differentiation and Function: Implications for the Treatment of Multiple Myeloma-Related Bone Disease," Journal of Cellular Physiology, Vol. 228, No. 7, 2012, pp.1506-1515. doi:10.1002/jcpp.24306

[128] R. Flavin, et al., "miR-29b Expression Is Associated with Disease-Free Survival in Patients with Ovarian Serous Carcinoma," International Journal of Gynecological Can- cer, Vol. 19, No. 4, 2009, pp. 641-647. doi:10.1111/IGC.0b013e3181a48cf9

[129] M. T. Di Martino, et al., "In Vitro and In Vivo Anti-Tumor Activity of miR-221/222 Inhibitors in Multiple Myeloma," Oncotarget, Vol. 4, No. 2, 2013, pp. 242-255.

[130] K. Wurz, et al., "miR-221 and miR-222 Alterations in Sporadic Ovarian Carcinoma: Relationship to CDKN1B, CDKNIC and Overall Survival," Genes Chromosomes Cancer, Vol. 49, No. 7, 2010, pp. 577-584.

[131]N. Amodio, et al., "miR-29b Sensitizes Multiple Myeloma Cells to Bortezomib-Induced Apoptosis through the Activation of a Feedback Loop with the Transcription Factor Sp1," Cell Death and Disease, Vol. 3, 2012, p. e436. doi:10.1038/cddis.2012.175

[132] N. Amodio, et al., "DNA-Demethylating and Anti-Tumor Activity of Synthetic miR-29b Mimics in Multiple Myeloma," Oncotarget, Vol. 3, No. 10, 2012, pp. 1246-1258. 